\title{
CORRESPONDENCE OF A. C. DODGE AND THOMAS H. BENTON ON THE PUBLIC LANDS, THE HOMESTEAD BILL, AND THE PACIFIC RAILROAD.
}

EDITED BY WILLIAM SALTER, D. D.

In the Thirty-second Congress, Mr. Dodge was chairman of the Committee on Public Lands in the Senate, and Mr. Benton was a member of the House of Representatives. After "Thirty Years in the Senate," Mr. Benton had been defeated for re-election to that body, because of his opposing $\mathrm{Mr}$. Douglas' measure for repealing the Compromise, under which Missouri came into the Union. He regarded that measure as a breach of faith, an act of dishonor.

In the Thirty-second Congress, the disposition of the Public Lands, the Homestead Bill, and the building of a railroad to the Pacific, were engrossing topics. It is to these questions that the correspondence refers:

Burlington, Iowa, November 11, 1852.

COLONEL Benton-

Dear Sir: The deep interest you have manifested in favor of a liberal and just disposition of the public domain, and your well known familiarity with the history, progress, and present condition of our Land System, will, I trust, be a sufficient apology for obtruding this letter upon you, and asking your opinion as to the merits of a Land Bill now attracting attention all over the country, known as "Bennett's Bill," 380 H. R. [After a full consideration of the bill, the letter proceeds.] Its authors are the deadly enemies of the alternate section railroad grants which passed the Senate for the benefit of those States in which public lands are situated, and still more hostile to the Homestead Bill granting 160 acres to every head of a family who may go into the wilderness, reside upon and cultivate his quarter section for five consecutive years-a measure which I think far surpasses all others in the benefits which it will confer, not only on the public land States, but on the entire Union.

The pillagers of the Treasury and Public Lands, whose operations at Washington you so appropriately described in a recent speech, have sent their emissaries into Iowa in the persons of $\mathbf{N}$. $\mathbf{Y}$. bankrupt contractors, who are seeking to influence the people and the legislature in favor of Bennett's Bill. One of this "pillager band," who 
imposed himself upon our Board of Internal Improvement, but failed to meet every engagement, was heard to say during the last session of Congress that he would be able to meet his contract for the improvement of the Des Moines, provided the "Sixty Million" bill (Bennett's) passed. That man boasts that he drew the bill. I write not to prejudice you against the measure, but as an item in the history of Congressional legislation.

: With high considerations of respect and esteem, Your friend,

A. C. DODGE.

Mr. Dodge was subsequently a member of a Select Committee to report a bill for the construction of a Pacific railroad. He made a vigorous speech on the subject in the Senate, Feb. 18, 1853, in which he advocated the route through Iowa, the valley of the Platte and the South Pass, and called attention "to what the accomplished and scientific Fremont had said respecting the practicability of the route, and of the most difficult portion of it." Previously to making that speech, he had received the following letter:

C Street, Tuesday night.

Hon. Augustus C. Dodge,

U. S. Senate, Senate Chamber.

Dear Sir: I have to thank you for the copy of the amendment to the Pacific Railroad Bill, reported by Mr. Rusk, and which you have had the kindness to send me, with a request for my remarks upon it. I give them freely.

1. I think the amendment is right in dispensing with branches, and going for one line through.

2. I suppose it as well to leave it to the President to fix the point of crossing the mountains, which of course fixes the points of termination.

3. I think the plan of execution is too complex-too much mixture of private interest and public expenditure-to admit of execution, and that, if gone into, there will be many balks, and eventual failure, and time lost, and a new start necessary.

4. I think the road should be either public or private-either made by the United States or by a joint stock company of adequate capital. The former I prefer. All the plans that I have seen propose the United States to furnish the means: then why not own the work when it is done? and make the freight and transportation so much the cheaper.

My idea is this: That the United States should build the road and fixtures, and then let it out to the lowest responsible bidder in point of rates for mails, passengers, freight, etc., for say 10 years at a time, the bidders furnishing and working their own cars; and if superseded by lower bidders at the end of say 10 years the new contractor to 
take all the stock of the previous one. I think it better for the United States to pay, like individuals, for everything she gets done. She will have to pay anyway, in a lump, if not in detail-and pretty sure in a big lump. A slight toll might be required to keep the road in repair; but with me cheapness of transportation is the object; and that is necessary to make the road a. great national thoroughfare. This is my first idea; after that a joint stock company which can raise an adequate sum, and make the road themselves, and run it themselves, having for . their main object profit, and of course the highest instead of the lowest rates-and so to diminish the use of the road.

Thus, you see, that $I$ do not think a mixed interest-part public and part private-will work well; and if the United States furnishes the means she ought to own the road, and make the use of it as cheap as possible to everybody.

On this plan she might create a stock at once of $\$ 100,000,000$, and raise every cent of it from the sale of lands as she goes along, and that upon the pre-emption principle. Settlers would be upon the whole line, like a flock of pigeons, the moment it was indicated, and raise crops immediately. In this way, with ample means, and beginning the road at both ends at onee, and perfecting 100 miles at a time, on which . cars could be placed to carry materials to the remainder, and also to help passengers a little, and I am sure that seven years would be enough. When done a daily train should be obligatory to start from each end.

I would not embarrass the Government with a telegraph-but assign a margin for as many lines as individuals or companies chose to put up.

The road should have a width of 1,000 feet, for if rightly located, it will want many tracks in process of time.

When Alexandria was the seat of Asiatic commerce the street which carried it was 1,000 feet wide, five miles long, and with 100 feet footway under colonades on each side.

The United States should make a common road also for people who have much time and little money.

Yours truly,

Thomas H. Benton.

Dry snow is no impediment to a car, no matter how deep. It is wet snow that impedes. This may now be seen without going to Russia. At Ogdensburg, N. Y., the cars have been seen to plough through 15 feet of snow without impediment, while a few inches of wet snow, $i$. e., snow in a soft climate, is a great impediment. This I learn from practical men-not from books.*

* The remarks of Mr. Benton in this note were put by Mr. Dodge into his speech delivered in the Senate, Feb. 18, 1853 . 
Copyright of Annals of Iowa is the property of State of Iowa, by \& through the State Historical Society of Iowa and its content may not be copied or emailed to multiple sites or posted to a listserv without the copyright holder's express written permission. However, users may print, download, or email articles for individual use. 